\title{
DEVELOPMENT OF FERTILIZER RECOMMENDATION FOR BLACKGRAM IN CHARLAND OF PABNA, BANGLADESH
}

\author{
M. Maniruzzaman ${ }^{1 *}$, M. R. Alam ${ }^{1}$, M.S. Islam ${ }^{1}$, M.Z. Islam ${ }^{1}$, M.S.H. Molla ${ }^{2}$ and M.A. Islam ${ }^{3}$ \\ ${ }^{1}$ On-farm Research Division, Bangladesh Agricultural Research Institute, Pabna \\ ${ }^{2}$ On-farm Research Division, Bangladesh Agricultural Research Institute, Rangpur \\ ${ }^{3}$ On-farm Research Division, Bangladesh Agricultural Research Institute, Shampur, Rajshahi \\ *Corresponding author, E-mail: maniruzzaman.bari@yahoo.com
}

(Received: 21 December 2017, Accepted: 23 March 2018)

Keywords: Charland, AEZ, Pulse, Blackgram, Yield, Cost and return

\begin{abstract}
The experiment was conducted at charland of Charsadipur in Pabna district under AEZ-11 during Khrif season of 2014 and 2015 to determine appropriate fertilizer dose for enhancing yield of blackgram as well as to increase farmers' income. The experiment was laid out in a randomized complete block design with four dispersed replications. Eight fertilizer packages, viz. $\mathrm{T}_{1}: \mathrm{N}_{20} \mathrm{P}_{15} \mathrm{~K}_{6} \mathrm{~S}_{9} \mathrm{Zn}_{2} \mathrm{~kg}$ ha ${ }^{-1}(\mathrm{STB}), \mathrm{T}_{2}$ : $\mathrm{N}_{25} \mathrm{P}_{15} \mathrm{~K}_{6} \mathrm{~S}_{9} \mathrm{Zn}_{2} \mathrm{~kg} \mathrm{ha}^{-1}, \mathrm{~T}_{3}: \mathrm{N}_{25} \mathrm{P}_{19} \mathrm{~K}_{6} \mathrm{~S}_{9} \mathrm{Zn}_{2} \mathrm{~kg} \mathrm{ha}^{-1}, \mathrm{~T}_{4}: \mathrm{N}_{25} \mathrm{P}_{15} \mathrm{~K}_{8} \mathrm{~S}_{9} \mathrm{Zn}_{2} \mathrm{~kg} \mathrm{ha}^{-1}, \mathrm{~T}_{5}:$ $\mathrm{N}_{20} \mathrm{P}_{19} \mathrm{~K}_{8} \mathrm{~S}_{9} \mathrm{Zn}_{2} \mathrm{~kg} \mathrm{ha}^{-1}, \mathrm{~T}_{6}: \mathrm{N}_{25} \mathrm{P}_{19} \mathrm{~K}_{15} \mathrm{~S}_{9} \mathrm{Zn}_{2} \mathrm{~kg} \mathrm{ha}^{-1}, \mathrm{~T}_{7}: \mathrm{N}_{15} \mathrm{P}_{11} \mathrm{~K}_{5} \mathrm{~S}_{7} \mathrm{Zn}_{1.5 k g} \mathrm{~kg}^{-1}$ and $\mathrm{T}_{8}$ : Native nutrients (control) were tested on blackgram. Fertilizer package of $\mathrm{N}_{25} \mathrm{P}_{19} \mathrm{~K}_{15} \mathrm{~S}_{9} \mathrm{Zn}_{2} \mathrm{~kg} \mathrm{ha}^{-1}\left(\mathrm{~T}_{6}\right)$ enhanced crop growth and yield of blackgram in both the years. Maximum seed yield of blackgram (1.43t ha- in 2014 and $0.97 \mathrm{t} \mathrm{ha}^{-1}$ in 2015) was obtained with $\mathrm{N}_{25} \mathrm{P}_{19} \mathrm{~K}_{15} \mathrm{~S}_{9} \mathrm{Zn}_{2} \mathrm{~kg} \mathrm{ha}^{-1}\left(\mathrm{~T}_{6}\right)$, which was 80 and $147 \%$ more than the control in 2014 and 2015, respectively. The highest gross return (Tk. 82815 ha $^{-1}$ in 2014 and Tk. $65200 \mathrm{ha}^{-1}$ in 2015) and gross margin (Tk. $51125 \mathrm{ha}^{-1}$ in 2014 and Tk. $32020 \mathrm{ha}^{-1}$ in 2015) were also recorded from the same treatment in both the years. The results revealed that fertilizer package of $\mathrm{N}_{25} \mathrm{P}_{19} \mathrm{~K}_{15} \mathrm{~S}_{9} \mathrm{Zn}_{2} \mathrm{~kg}$ ha ${ }^{-1}$ might be recommended for getting higher seed yield of blackgram and economic return as well under charland condition of Pabna district
\end{abstract}

\section{Introduction}

Pulses are vital legume crops in Bangladesh and used as food, feed and fodder. It is rich in protein. It also contains amino acid and lysine which are generally deficient in food grains (Elias et al., 1986). Pulses play an important role in sustaining soil health. They are generally grown without fertilizer since they can meet their nitrogen requirement by symbiotic fixation of atmospheric nitrogen in the soil (Senanayake et al., 1987; Zapata et al., 1987; Fried and Middleboe, 1977). The per capita consumption of pulse in Bangladesh is only $12 \mathrm{~g} \mathrm{day}^{-1}$, which is much lower than WHO recommendation of $45 \mathrm{~g} \mathrm{day}^{-1}$ (Afzal et al., 1999).

Blackgram (Vigna mungo L.), one of the major pulse crop, stands fourth both in acreage and production in Bangladesh. Blackgram provides about $10.5 \%$ of the total pulse produced in Bangladesh and its seed contains about $25 \%$ protein (BARI, 1998). It is mainly grown for human consumption, though widely used as fodder for cattle and green manuring crop to improve soil fertility.

In Bangladesh the char lands of char area are not suitable for all types of crop. In Pabna, there is a vast area of charland under AEZ-11. Soil of charland is coarse textured having low water holding capacity, low nutrient and organic matter content. Farmers of charland in Pabna generally grow local variety of blackgram with no or limited fertilizers. For this reason, the 
yield of blackgram in this region ismuch lower than that of potential yield. Balanced fertilization can play a major role toenhance the present yield level. Experimental evidences reveal that the crop is highly responsive to different fertilizers and its yieldcan be increased remarkably through judicious fertilization (BARI, 1988; Mohamed, 1984; Roy and Singh, 1986; Kazi et al., 2002). Fertilizer recommendation solely based on crop response data often fails to show economic viability. In this context, Perrin et al. (1979) reported that response of yield should be supported by economic evaluation for judicious fertilizer recommendation. Therefore, judicious application of fertilizer along with economic evaluation is important for blackgram. But very limited information is available in this regard in Bangladesh context. Hence, the present study was undertaken to determine the optimum fertilizerdose for getting higher economic benefit for blackgram in charland of Pabna district.

\section{Materials and Method}

The experiment was conducted at charland of Charsadipur in Pabna district during the Khrif-II season of 2014 and 2015. Soil series of the experimental site was Gopalpur belonging to the High Ganges River Floodplain Soils (AEZ-11). Before sowing, initial soil samples $(0-15 \mathrm{~cm}$ depth) were collected from the experimental plots and were analyzed. The analytical results indicated that soil was sandy loam with verylow organic matter content $(0.78 \%)$ and slightly alkaline in nature. $\mathrm{N}$ content of soil was very low and $\mathrm{P}, \mathrm{S}$ and Zncontent were also low. $\mathrm{K}$ content of the soil was medium (Table 1). The experiment was laid out in randomized complete block (RCB) design with three dispersed replications. The unit plot size was $5 \mathrm{~m} \times 4 \mathrm{~m}$.

Table 1. Nutrient status of initial soil sample $(0-15 \mathrm{~cm}$ depth $)$ of experimental plots at Charsadipur, Pabna.

\begin{tabular}{lcc}
\hline Soil properties & Values & Interpretation \\
\hline Soil $\mathrm{pH}$ & 8.1 & Slightly alkaline \\
Organic matter content $(\%)$ & 0.78 & Very low \\
Total N $(\%)$ & 0.05 & Very low \\
Available $\mathrm{P}\left(\mu \mathrm{gg}^{-1}\right.$ soil) & 11.6 & Low \\
Available $\mathrm{S}\left(\mu \mathrm{gg}^{-1}\right.$ soil) & 9.3 & Low \\
Available $\mathrm{Zn}^{-} \mu \mathrm{gg}^{-1}$ soil) & 0.56 & Low \\
Exchangeable K $(\mathrm{meq} \%)$ & 0.18 & Medium \\
\hline
\end{tabular}

$\mathrm{T}_{1}: \mathrm{N}_{20} \mathrm{P}_{15} \mathrm{~K}_{12} \mathrm{~S}_{9} \mathrm{Zn}_{2} \mathrm{~kg} \mathrm{ha}^{-1}(\mathrm{STB}), \mathrm{T}_{2}: \mathrm{N}_{25} \mathrm{P}_{15} \mathrm{~K}_{12} \mathrm{~S}_{9} \mathrm{Zn}_{2} \mathrm{~kg} \mathrm{ha}^{-1}, \mathrm{~T}_{3}: \mathrm{N}_{25} \mathrm{P}_{19} \mathrm{~K}_{12} \mathrm{~S}_{9} \mathrm{Zn}_{2} \mathrm{kgha}^{-1}$,

$\mathrm{T}_{4}: \mathrm{N}_{25} \mathrm{P}_{15} \mathrm{~K}_{15} \mathrm{~S}_{9} \mathrm{Zn}_{2} \mathrm{kgha}^{-1}, \mathrm{~T}_{5}: \mathrm{N}_{20} \mathrm{P}_{19} \mathrm{~K}_{15} \mathrm{~S}_{9} \mathrm{Zn}_{2} \mathrm{kgha}^{-1}, \mathrm{~T}_{6}: \mathrm{N}_{25} \mathrm{P}_{19} \mathrm{~K}_{15} \mathrm{~S}_{9} \mathrm{Zn}_{2} \mathrm{~kg} \mathrm{ha}^{-1}, \mathrm{~T}_{7}: \mathrm{N}_{15} \mathrm{P}_{11} \mathrm{~K}_{9} \mathrm{~S}_{7} \mathrm{Zn}_{1.5} \mathrm{~kg}$ $\mathrm{ha}^{-1}$ and $\mathrm{T}_{8}$ : native nutrient (control).

Full amount of all fertilizers were applied as basal according to treatments. Seeds of blackgram were broadcasted in each plot on 15-20 August maintaining the seed rate of $35 \mathrm{~kg} \mathrm{ha}^{-1}$ in both the year. The variety used this trial was BARI Mash-3. Two weedings were done at 25 and 40 days after sowing (DAS) for better growth of the crop. Ripcord 50 EC was applied at 35 DAS to control leaf feeding insect. Other intercultural operations were done when required. The above ground part of blackgram was harvested on 10-15 November in both the year. Data on days to $50 \%$ flowering, days to $80 \%$ maturity were taken from all plots. Plant height, pods plant ${ }^{1}$,seeds pod $^{-1}$ and 1000 -seed weight were collected from randomly selected 10 plants at maturity stage from each plot. Seed yield and stover yield were taken from whole plot. All collected data were analyzed statistically by using MSTAT package and the means were adjudged by LSD test at $5 \%$ level of significance. Cost and return analysis of different treatments were also done .

\section{Results and Discussion}




\section{Phenological characters}

Phenological characters ofblackgram have been presented in Table 2. Significant variation in days to $50 \%$ flowering, days to $80 \%$ maturity and plant height were observed due to execution of different treatments. Maximum days to 50\% flowering (53 in 2014 and52 in 2015 ) and days to $80 \%$ maturity (74 in 2014and 83 in 2015 ) were recorded from $\mathrm{N}_{25} \mathrm{P}_{19} \mathrm{~K}_{15} \mathrm{~S}_{9} \mathrm{Zn}_{2} \mathrm{~kg} \mathrm{ha}^{-1}\left(\mathrm{~T}_{6}\right)$ which was statistically different from all other fertilizer packages while minimum days to $50 \%$ flowering (46.67 in 2014 and 45.67 in 2015) and days to 80\% maturity (70.67 in 2014 and 77.67 in 2015) were recorded from control plot $\left(\mathrm{T}_{8}\right)$. The highest plant height $(38.0 \mathrm{~cm}$ in 2014 and $50.3 \mathrm{~cm}$ in 2015) was measured from $\mathrm{N}_{25} \mathrm{P}_{19} \mathrm{~K}_{15} \mathrm{~S}_{9} \mathrm{Zn}_{2} \mathrm{~kg} \mathrm{ha}^{-1}\left(\mathrm{~T}_{6}\right)$ and the lowest plant height $(33.43 \mathrm{~cm}$ in 2014 and $38.62 \mathrm{~cm}$ in 2015$)$ was recorded in control plot $\left(\mathrm{T}_{8}\right)$.

Table 2. Phenological parameters of blackgram as affected by different levels of nutrients during kharif season of 2014 and 2015 at Charsadipur, Pabna

\begin{tabular}{|c|c|c|c|c|c|c|}
\hline \multirow[t]{2}{*}{ Treatment } & \multicolumn{2}{|c|}{$\begin{array}{c}\text { Days to } 50 \% \\
\text { flowering } \\
\text { (no.) }\end{array}$} & \multicolumn{2}{|c|}{$\begin{array}{c}\text { Days to } 80 \% \\
\text { maturity } \\
\text { (no.) }\end{array}$} & \multicolumn{2}{|c|}{$\begin{array}{l}\text { Plant height } \\
(\mathrm{cm})\end{array}$} \\
\hline & 2014 & 2015 & 2014 & 2015 & 2014 & 2015 \\
\hline $\begin{array}{l}\mathrm{T}_{1}: \quad \mathrm{N}_{20} \mathrm{P}_{15} \mathrm{~K}_{12} \mathrm{~S}_{9} \mathrm{Zn}_{2} \quad \mathrm{~kg} \quad \mathrm{ha}^{-1} \\
\text { (STB) }\end{array}$ & 48.33 & 47.33 & 72.00 & 80.33 & 36.27 & 38.95 \\
\hline $\mathrm{T}_{2}: \mathrm{N}_{25} \mathrm{P}_{15} \mathrm{~K}_{6} \mathrm{~S}_{9} \mathrm{Zn}_{2} \mathrm{~kg} \mathrm{ha}^{-1}$ & 50.33 & 49.33 & 72.33 & 82.00 & 37.23 & 39.99 \\
\hline $\mathrm{T}_{3}: \mathrm{N}_{25} \mathrm{P}_{19} \mathrm{~K}_{6} \mathrm{~S}_{9} \mathrm{Zn}_{2} \mathrm{~kg} \mathrm{ha}^{-1}$ & 50.67 & 49.67 & 73.00 & 81.67 & 37.63 & 43.66 \\
\hline $\mathrm{T}_{4}: \mathrm{N}_{25} \mathrm{P}_{15} \mathrm{~K}_{15} \mathrm{~S}_{9} \mathrm{Zn}_{2} \mathrm{~kg} \mathrm{ha}^{-1}$ & 51.33 & 50.33 & 73.00 & 81.33 & 36.20 & 45.30 \\
\hline $\mathrm{T}_{5}: \mathrm{N}_{20} \mathrm{P}_{19} \mathrm{~K}_{15} \mathrm{~S}_{9} \mathrm{Zn}_{2} \mathrm{~kg} \mathrm{ha}^{-1}$ & 51.00 & 50.00 & 72.67 & 80.67 & 35.67 & 43.68 \\
\hline $\mathrm{T}_{6}: \mathrm{N}_{25} \mathrm{P}_{19} \mathrm{~K}_{15} \mathrm{~S}_{9} \mathrm{Zn}_{2} \mathrm{~kg} \mathrm{ha}^{-1}$ & 53.00 & 52.00 & 74.00 & 83.00 & 38.00 & 50.30 \\
\hline $\mathrm{T}_{7}: \mathrm{N}_{15} \mathrm{P}_{11} \mathrm{~K}_{9} \mathrm{~S}_{7} \mathrm{Zn}_{1.5} \mathrm{~kg} \mathrm{ha}^{-1}$ & 47.67 & 46.67 & 71.67 & 79.33 & 36.40 & 42.34 \\
\hline $\mathrm{T}_{8}:$ Control & 46.67 & 45.67 & 70.67 & 77.67 & 33.43 & 38.62 \\
\hline $\operatorname{LSD}_{(0.05)}$ & 0.908 & 0.90 & 1.186 & 0.84 & 1.415 & 5.92 \\
\hline $\mathrm{CV}(\%)$ & 6.04 & 5.06 & 8.67 & 6.60 & 7.60 & 6.38 \\
\hline
\end{tabular}

\section{Yield contributing characters}

Yield contributing characters of blackgram are presented in Table 3. Significant variation in number of pods plant ${ }^{-1}$, number of seeds pod ${ }^{-1}$, and 1000 -seed weight were observed due to execution of different treatments. Maximum number of pod plant ${ }^{-1}(24.47$ in 2014 and 18.17 in 215) was found from $\mathrm{N}_{25} \mathrm{P}_{19} \mathrm{~K}_{15} \mathrm{~S}_{9} \mathrm{Zn}_{2} \mathrm{~kg} \mathrm{ha}^{-1}\left(\mathrm{~T}_{6}\right)$ in both the year while minimumnumber of pods plant ${ }^{-1}$ (17.27 in 2014 and 14.23 in 2015) was recorded from control plot ( $\left.\mathrm{T}_{8}\right)$. In case of number of seeds pod ${ }^{-1}$, no significant difference was found among the treatments except control. Significantly higher 1000-seed weight was observed from in all the fertilizer packages over control in both the years and the lowest 1000 -seed weight $(33.63 \mathrm{~g}$ in 2014 and $34.67 \mathrm{~g}$ in 2015) from control plot $\left(\mathrm{T}_{8}\right)$.

Table 3. Yield contributing parameters of blackgram as affected by different levels of nutrients during kharifseason of 2014 and 2015 at Charsadipur, Pabna

\begin{tabular}{lcccccc}
\hline \multicolumn{1}{c}{ Treatments } & \multicolumn{2}{c}{$\begin{array}{c}\text { Pods plant } \\
\text { (no.) }\end{array}$} & \multicolumn{2}{c}{$\begin{array}{c}\text { Seeds pod } \\
\text { (no.) }\end{array}$} & \multicolumn{2}{c}{$\begin{array}{c}\text { 1000-seed } \\
\text { weight } \\
\text { (g) }\end{array}$} \\
\cline { 2 - 7 } & 2014 & 2015 & 2014 & 2015 & 2014 & 2015 \\
\hline $\mathrm{T}_{1}: \mathrm{N}_{20} \mathrm{P}_{15} \mathrm{~K}_{12} \mathrm{~S}_{9} \mathrm{Zn}_{2} \mathrm{~kg} \mathrm{ha}^{-1}(\mathrm{STB})$ & 19.44 & 16.73 & 6.850 & 6.32 & 34.77 & 34.90 \\
$\mathrm{~T}_{2}: \mathrm{N}_{25} \mathrm{P}_{15} \mathrm{~K}_{6} \mathrm{~S}_{9} \mathrm{Zn}_{2} \mathrm{~kg} \mathrm{ha}^{-1}$ & 20.04 & 16.97 & 6.900 & 6.37 & 34.80 & 34.93
\end{tabular}




\begin{tabular}{lcccccc}
$\mathrm{T}_{3}: \mathrm{N}_{25} \mathrm{P}_{19} \mathrm{~K}_{6} \mathrm{~S}_{9} \mathrm{Zn}_{2} \mathrm{~kg} \mathrm{ha}^{-1}$ & 21.07 & 18.07 & 7.010 & 6.53 & 34.90 & 34.97 \\
$\mathrm{~T}_{4}: \mathrm{N}_{25} \mathrm{P}_{15} \mathrm{~K}_{15} \mathrm{~S}_{9} \mathrm{Zn}_{2} \mathrm{~kg} \mathrm{ha}^{-1}$ & 19.30 & 17.63 & 7.060 & 6.50 & 35.27 & 35.13 \\
$\mathrm{~T}_{5}: \mathrm{N}_{20} \mathrm{P}_{19} \mathrm{~K}_{15} \mathrm{~S}_{9} \mathrm{Zn}_{2} \mathrm{~kg} \mathrm{ha}^{-1}$ & 20.81 & 17.83 & 6.830 & 6.77 & 35.17 & 35.47 \\
$\mathrm{~T}_{6}: \mathrm{N}_{25} \mathrm{P}_{19} \mathrm{~K}_{15} \mathrm{~S}_{9} \mathrm{Zn}_{2} \mathrm{~kg} \mathrm{ha}^{-1}$ & 24.47 & 18.17 & 6.767 & 6.83 & 35.40 & 35.90 \\
$\mathrm{~T}_{7}: \mathrm{N}_{15} \mathrm{P}_{11} \mathrm{~K}_{9} \mathrm{~S}_{7} \mathrm{Zn}_{1.5} \mathrm{~kg} \mathrm{ha}^{-1}$ & 18.04 & 15.67 & 6.50 & 6.00 & 34.73 & 35.00 \\
$\mathrm{~T}_{8}:$ Control & 17.27 & 14.23 & 6.37 & 5.67 & 33.63 & 34.67 \\
\hline $\mathrm{LSD}(0.05)$ & 3.24 & 2.125 & 0.65 & 0.53 & 0.896 & 1.088 \\
$\mathrm{CV}(\%)$ & 9.25 & 5.17 & 5.49 & 2.45 & 1.47 & 1.77 \\
\hline
\end{tabular}

Yield and percent yield increase over control of blackgram have been presented in Table 4.Maximum stover yield of blackgram (1.77 t ha-1 in 2014 and $1.4 \mathrm{t} \mathrm{ha}^{-1}$ in 2015) was found from $\mathrm{N}_{25} \mathrm{P}_{19} \mathrm{~K}_{15} \mathrm{~S}_{9} \mathrm{Zn}_{2} \mathrm{~kg} \mathrm{ha}^{-1}\left(\mathrm{~T}_{6}\right)$ treatment and minimum stover yield $\left(0.97 \mathrm{t} \mathrm{ha}^{-1}\right.$ in 2014 and $1.0 \mathrm{t} \mathrm{ha}^{-1}$ in 2015) was found from control plot $\left(\mathrm{T}_{8}\right)$. The highest seed yield $\left(1.43 \mathrm{t} \mathrm{ha}^{-1}\right.$ in 2014 and $0.97 \mathrm{t} \mathrm{ha}^{-1}$ in 2015) was obtained from $\mathrm{N}_{25} \mathrm{P}_{19} \mathrm{~K}_{15} \mathrm{~S}_{9} \mathrm{Zn}_{2} \mathrm{~kg} \mathrm{ha}^{-1}\left(\mathrm{~T}_{6}\right)$ which was significantly higher than other treatments. On the contrary, control $\left(\mathrm{T}_{8}\right)$ treatment provided the lowest seed yield (0.58 t ha-1in 2014 and $0.54 \mathrm{t} \mathrm{ha}^{-1}$ in 2015). The cumulative contribution of yield components might be the reason for higher seed yield in $\mathrm{N}_{25} \mathrm{P}_{19} \mathrm{~K}_{15} \mathrm{~S}_{9} \mathrm{Zn}_{2} \mathrm{~kg} \mathrm{ha}^{-1}\left(\mathrm{~T}_{6}\right)$. In contrast, poor crop growth and lower yield components resulted the lowest seed yield in control treatment $\left(\mathrm{T}_{8}\right)$. Yield increase over control (147\% in 2014 and $80 \%$ in 2015) was more in $\mathrm{N}_{25} \mathrm{P}_{19} \mathrm{~K}_{15} \mathrm{~S}_{9} \mathrm{Zn}_{2} \mathrm{~kg} \mathrm{ha}^{-1}\left(\mathrm{~T}_{6}\right)$. The overall results indicated that $100 \%$ soil test based fertilizer package plus $25 \%$ additional nutrients specially $\mathrm{N}, \mathrm{P}$ and $\mathrm{K}$ that is fertilizer dose of $\mathrm{N}_{25} \mathrm{P}_{19} \mathrm{~K}_{15} \mathrm{~S}_{9} \mathrm{Zn}_{2} \mathrm{~kg} \mathrm{ha}^{-1}\left(\mathrm{~T}_{6}\right)$ enhance plant growth and produced higher yield in blackgram. This result is supported by the findings of Kumar and Singh (2009), Mondal et al. (2010); Bhuiyan et al. (2008) and Singh et al. (2004) in case of lentil.They reported that balanced application of $\mathrm{N}, \mathrm{P}, \mathrm{K}, \mathrm{S}, \mathrm{Zn}$ and B significantly increased yield of lentil over control.

\section{Cost and return analysis}

Cost and return analysis demonstrated that maximum gross return (Tk. 94,650 ha ${ }^{-1}$ in 2014 and Tk. 65,200 ha- in 2015) and gross margin (Tk. 62,960 ha-1 in 2014 and Tk. $32020 \mathrm{ha}^{-1}$ in 2015) was obtained from $\mathrm{N}_{25} \mathrm{P}_{19} \mathrm{~K}_{15} \mathrm{~S}_{9} \mathrm{Zn}_{2} \mathrm{~kg} \mathrm{ha}^{-1}\left(\mathrm{~T}_{6}\right)$ followed by $\mathrm{T}_{4}$ and $\mathrm{T}_{5}$ fertilizer packages (Table 5). Higher production in this treatment resulted in higher economic return. Total variable cost in different treatments varied mainly due to involvement of fertilizer cost. Minimum gross margin (Tk. 12,500 ha- in 2014 and Tk. 8,650 in 2015 ha $^{-1}$ ) was recorded in control plot $\left(\mathrm{T}_{8}\right)$ might be due to lower yield.

Table 4. Seed yield of blackgram as affected by different levels of nutrients during the kharifseason of 2014 and 2015 at Charsadipur, Pabna

\begin{tabular}{lcccccc}
\hline \multirow{2}{*}{ Treatments } & \multicolumn{2}{c}{$\begin{array}{c}\text { Stover yield } \\
\left(\mathrm{t} \mathrm{ha}^{-1}\right)\end{array}$} & \multicolumn{2}{c}{$\begin{array}{c}\text { Seed yield } \\
(\mathrm{t} \mathrm{ha}\end{array}$} & \multicolumn{2}{c}{$\begin{array}{c}\text { Seed yield increase } \\
\text { over control }(\%)\end{array}$} \\
\cline { 2 - 7 } & 2014 & 2015 & 2014 & 2015 & 2014 & 2015 \\
\hline $\mathrm{T}_{1}: \mathrm{N}_{20} \mathrm{P}_{15} \mathrm{~K}_{12} \mathrm{~S}_{9} \mathrm{Zn}_{2} \mathrm{~kg} \mathrm{ha}^{-1}(\mathrm{STB})$ & 1.22 & 1.23 & 0.80 & 0.68 & 38 & 26 \\
$\mathrm{~T}_{2}: \mathrm{N}_{25} \mathrm{P}_{15} \mathrm{~K}_{6} \mathrm{~S}_{9} \mathrm{Zn}_{2} \mathrm{~kg} \mathrm{ha}^{-1}$ & 1.33 & 1.29 & 0.86 & 0.77 & 48 & 43 \\
$\mathrm{~T}_{3}: \mathrm{N}_{25} \mathrm{P}_{19} \mathrm{~K}_{6} \mathrm{~S}_{9} \mathrm{Zn}_{2} \mathrm{~kg} \mathrm{ha}^{-1}$ & 1.37 & 1.25 & 0.96 & 0.67 & 67 & 24 \\
$\mathrm{~T}_{4}: \mathrm{N}_{25} \mathrm{P}_{15} \mathrm{~K}_{15} \mathrm{~S}_{9} Z_{2} \mathrm{~kg} \mathrm{ha}^{-1}$ & 1.37 & 1.30 & 1.10 & 0.83 & 90 & 54 \\
$\mathrm{~T}_{5}: \mathrm{N}_{20} \mathrm{P}_{19} \mathrm{~K}_{15} \mathrm{~S}_{9} \mathrm{Zn}_{2} \mathrm{~kg} \mathrm{ha}^{-1}$ & 1.40 & 1.24 & 1.27 & 0.69 & 119 & 28 \\
$\mathrm{~T}_{6}: \mathrm{N}_{25} \mathrm{P}_{19} \mathrm{~K}_{15} \mathrm{~S}_{9} \mathrm{Zn}_{2} \mathrm{~kg} \mathrm{ha}^{-1}$ & 1.77 & 1.40 & 1.43 & 0.97 & 147 & 80 \\
$\mathrm{~T}_{7}: \mathrm{N}_{15} \mathrm{P}_{11} \mathrm{~K}_{9} \mathrm{~S}_{7} \mathrm{Zn}_{1.5} \mathrm{~kg} \mathrm{ha}^{-1}$ & 1.20 & 1.08 & $0.74 \mathrm{~d}$ & 0.66 & 28 & 22 \\
$\mathrm{~T}_{8}: \mathrm{Con}_{1} \mathrm{C}$ & 0.97 & 1.00 & 0.58 & 0.54 & - & - \\
\hline $\mathrm{LSD}$ & 0.33 & 0.39 & 0.236 & 0.21 & - & - \\
$\mathrm{CV}(\%)$ & 10.31 & 18.48 & 9.70 & 19.72 & - & - \\
\hline
\end{tabular}


Table 5. Cost and return analysis of blackgram influenced by fertilizer packages at Charsadipur, Pabna as affected by different levels of nutrients during Kharif season of 2014 and 2015

\begin{tabular}{|c|c|c|c|c|c|c|}
\hline \multirow[t]{2}{*}{ Treatments } & \multicolumn{2}{|c|}{$\begin{array}{l}\text { Gross return } \\
\left(\mathrm{Tk}_{\mathrm{h}} \mathrm{ha}^{-1}\right)\end{array}$} & \multicolumn{2}{|c|}{$\begin{array}{l}\text { Total variable cost } \\
\left(\mathrm{Tk}^{\left.-h^{-1}\right)}\right.\end{array}$} & \multicolumn{2}{|c|}{$\begin{array}{l}\text { Gross margin } \\
\left(\mathrm{Tk}_{\mathrm{ha}} \mathrm{ha}^{-1}\right)\end{array}$} \\
\hline & 2014 & 2015 & 2014 & 2015 & 2014 & 2015 \\
\hline $\begin{array}{l}\mathrm{T}_{1}: \mathrm{N}_{20} \mathrm{P}_{15} \mathrm{~K}_{12} \mathrm{~S}_{9} \mathrm{Zn}_{2} \quad \mathrm{~kg} \mathrm{ha} \mathrm{ha}^{-1} \\
(\mathrm{STB})\end{array}$ & 54100 & 46950 & 30780 & 32294 & 23320 & 14656 \\
\hline $\mathrm{T}_{2}: \mathrm{N}_{25} \mathrm{P}_{15} \mathrm{~K}_{6} \mathrm{~S}_{9} \mathrm{Zn}_{2} \mathrm{~kg} \mathrm{ha}^{-1}$ & 58250 & 52650 & 30980 & 32470 & 27270 & 20180 \\
\hline $\mathrm{T}_{3}: \mathrm{N}_{25} \mathrm{P}_{19} \mathrm{~K}_{6} \mathrm{~S}_{9} \mathrm{Zn}_{2} \mathrm{~kg} \mathrm{ha}^{-1}$ & 64450 & 46450 & 31530 & 33020 & 32920 & 13430 \\
\hline $\mathrm{T}_{4}: \mathrm{N}_{25} \mathrm{P}_{15} \mathrm{~K}_{15} \mathrm{~S}_{9} \mathrm{Zn}_{2} \mathrm{~kg} \mathrm{ha}^{-1}$ & 72850 & 56300 & 31140 & 32630 & 41710 & 23670 \\
\hline $\mathrm{T}_{5}: \mathrm{N}_{20} \mathrm{P}_{19} \mathrm{~K}_{15} \mathrm{~S}_{9} \mathrm{Zn}_{2} \mathrm{~kg} \mathrm{ha}^{-1}$ & 83200 & 47600 & 31490 & 33004 & 51710 & 14596 \\
\hline $\mathrm{T}_{6}: \mathrm{N}_{25} \mathrm{P}_{19} \mathrm{~K}_{15} \mathrm{~S}_{9} \mathrm{Zn}_{2} \mathrm{~kg} \mathrm{ha}^{-1}$ & 94650 & 65200 & 31690 & 33180 & 62960 & 32020 \\
\hline $\mathrm{T}_{7}: \mathrm{N}_{15} \mathrm{P}_{11} \mathrm{~K}_{9} \mathrm{~S}_{7} \mathrm{Zn}_{1.5} \mathrm{~kg} \mathrm{ha}^{-1}$ & 49800 & 45000 & 29875 & 31400 & 19925 & 13600 \\
\hline $\mathrm{T}_{8}:$ Control & 39650 & 37400 & 27150 & 28750 & 12500 & 8650 \\
\hline
\end{tabular}

Market Price (Tk. $\mathrm{kg}^{-1}$ ): Blackgram: Grain 60.00, Straw 5.00

\section{Conclusion}

The results revealed that fertilizer packages exerted significant effect on growth and yield of blackgram. Blackgram grown with $\mathrm{N}_{25} \mathrm{P}_{19} \mathrm{~K}_{15} \mathrm{~S}_{9} \mathrm{Zn}_{2} \mathrm{~kg} \mathrm{ha}^{-1}$ produced the highest yield and gave the maximum economic benefit at charland area of Pabna district, Bangladesh.

\section{References}

Afzal, M. A., M. A. Bakr and M. L. Rahman. 1999. Lentil cultivation in Bangladesh. Lentil, Blackgram and Mungbean Development Pilot Project, Pulses Research Station, BARI, Gazipur-1701.

BARI (Bangladesh Agricultural Research Institute). 1988. Annual Report 1988-89, pp. 136-142. BARI, Joydebpur, Gazipur-1701, Bangladesh.

Bhuiyan, M.A.H., D. Khanam, N.E. Ali, M.K. Zaman and M.S. Islam. 2008. Response of lentil to bio fertilizer and chemical fertilizers in the farmers' field. Annual Research Report, 20072008, Soil Science Division, BARI, Gazipur.

Elias. S.M., M.S. Hossain, F.S. Sikder, J. Ahmed and M. R.Karim. 1986. Identification of constraints to pulse production with special reference to present farming systems. Annual Report of Agricultural Economic Division, BARI, Joydebpur.p-1.

Fried, M. and V. Middelboe. 1977. Measurement of amount of nitrogen fixed by legume crop. Plant and Soil 47: 713-715.

Kazi, B. R., F. C.Oad, and A. Lakho. 2002.Effect of irrigation frequencies on growth and yield of soybean. Pakistan J. Appl. Sci. 2 (6): 661-662.

Kumar, S. and M. Singh . 2009. 25 Years of Pulses Research at IIPR, 1984-2009. Indian Institute of Pulses Research, Kanpur 208024, India.

Mohamed, S. A. 1984. Effect of irrigation water and fertilization on yield and water use efficiency of corn plants in Fayoum Governorate. Moshtohor, Egypt Annual Agric. Sci. 20(2): 221-235.

Mondal, R.H., B. Anwar, M. Rafiuddin and M.A. Hossain. 2010. Integrated nutrient management $\mathrm{f}$ or sustaining soil fertility and yield of Lentil-Mungbean-T.Aman cropping pattern. Annual Research Report, 2009-2010, Pulses Research Centre, BARI, Gazipur. 
Perrin, R. K., D. L.Winkelmen, E. R. Moscardi, andJ. R. Anderson. 1979.Economic Training Manual. Information Bulletin No. 27. CIMMYT, Mexico. 5 p.

Roy, R. K. and K. S. P. Singh. 1986. Response of pop-corn (Zea mays) to plant population and nitrogen. Indian J. Agron. 31(1): 87-92.

Senanayake. L., D.P. Knievel, S.E. Stevena. 1987. Nodulation and symbiotic nitrogen fixation of cowpea (Vigna unguiculata L.). Plant and Soil 99: 435-439.

Singh, S.K., S.C. Varmaand and R.P. Singh. 2004. Residual effect of organic and inorganic sources of nutrients in lowland rice on succeeding lentil. Indian J. Agric. Res., 38(2): 121-125

Zapata. F., S.K.A. Danso, G. Hardarson and M. Fried. 1987. Nitrogen fixation and translocation in field-grown fababean. Agron. J. 79: 505-509. 